\title{
INDIVIDUAL CHARACTERISTICS AFFECTING PARTICIPATION IN URBAN AND COMMUNITY FORESTRY PROGRAMS IN SOUTH CAROLINA, U.S.
}

\author{
By Thomas J. Straka1, Allan P. Marsinko1, and Christopher J. Childers²
}

\begin{abstract}
This article reports the results of a 2003 statewide survey of South Carolina, U.S., residents concerning characteristics affecting participation in urban and community forestry programs. Results are intended to increase effectiveness of program planning and organization within state forestry commissions. Participants in urban and community forestry programs have strong feelings for the importance of these programs, and the majority (91\%) expected continued participation. The majority of nonparticipants (71\%) were unaware of the existence of these programs, and most (59\%) did not know whether they would ever participate in future programs. Future considerations for the success of urban and community forestry programs in South Carolina need to focus on increased public awareness. Prior awareness of the program and participant's age significantly $(P \leq 0.10)$ affected stated intentions to participate in the program.
\end{abstract}

Key Words. Urban and community forestry; community forestry; urban forestry; tree programs.

At the turn of the century, over three-quarters of United States' residents lived in urban areas (Alig et al. 1999; U.S. Department of Commerce 2000). The urban forest has an important impact on the qualities of their lives (Alig et al. 2003). Congress realized this when it amended the Cooperative Forestry Assistance Act of 1978 to authorize financial, technical, and related assistance to state foresters in support of cooperative efforts in urban and community forestry (Cubbage et al. 1993). Between 1960 and 1997, the nation's urban area increased from 10.2 to 26.7 million ha (25 to 66 million ac) (Vesterby and Krupa 2001). Over the 48 contiguous states, in 1992 less than 3\% of land area was urban and less than $5 \%$ of the land area was considered developed (Heimlich and Anderson 2001). Urban land area in 1997 varied from 10\% in the northeast to $1 \%$ in the mountain region (Vesterby and Krupa 2001). Urbanization is tied to population growth, and by 2050 another 16.2 million ha (40 million ac) is expected to be converted to urban and other development uses (Alig et al. 2003). South Carolina follows this national trend (London and Hill 2000).

The urban forest produces significant benefits. It has a positive impact on the physical environment (increased property value and reduced energy costs and water runoff), social environment (community health and well-being, consumer behavior, recreational opportunities, reduced noise levels, and creation of buffer zones), and the natural environment (decreased soil erosion and improvements in wildlife habitat and air and water quality) (McPherson 1994; Nowak 1994). Typical planning assistance from urban and community forestry programs includes urban and community forestry planning; recreational development; air and water quality improvement programs; stormwater management; urban wildlife management; and urban development and conservation management plans.

Within the United States, typical program recipients are local governments, policy makers and elected officials, builders and developers, civic and community groups, neighborhood associations, nonprofit groups, local businesses, and urban forest councils (USDA Forest Service 2004).

A major initiative in U.S. urban and community forestry began in 1991 with a national program designed to improve the awareness, management, conservation, and care of the tree resources in and around communities. A centerpiece of the program was a competitive grants program, funded by the USDA Forest Service and administered by state forestry commissions, designed to "improve understanding of the benefits of preserving existing tree cover, provide educational programs and technical assistance to state and local organizations, provide assistance through competitive matching grants for urban and community forestry projects, establish demonstration projects to illustrate the benefits of forest cover and trees, and to enhance the technical skills of individuals involved in the planning, development and maintenance of urban and community forests" (South Carolina Forestry Commission 2004).

The goal of these programs at the state level is to improve and manage the forest resources in and around urban environments. There are three main components of urban and community forestry at the state level: information dissemination, technical assistance, and financial assistance. As a form of information dissemination, many states encourage their communities to achieve Tree City USA recognition, a program that acknowledges community achievements in urban tree management (National Arbor Day Foundation 2004). Funding for technical assistance often allows the state forestry agency to employ urban 
foresters, who are available to provide insight on community projects. Financial assistance refers to the various grants available for each state that provide for projects such as tree planting, educational workshops, and community tree inventories. Program information is given to the public through brochures, Web sites, and meetings.

Technical and financial assistance are most commonly available through the state forestry commission or department of natural resources agencies, which have access to funding for these types of projects. This assistance can come in one of four forms: technical assistance, education and training, resource development, and public awareness (Wisconsin DNR 2004). Financial assistance can range anywhere from US $\$ 1,000$ for tree planting projects to US $\$ 25,000$ for education/training development (Florida Division of Forestry 2004; South Carolina Forestry Commission 2004; Wisconsin DNR 2004). In most cases, these awards are matching grants, meaning that the grantee must match the agency dollar for dollar.

Citizen involvement in the public planning process is often described as a "ladder of participation" (Arnstein 1969), for which the level of participation is defined in terms of ladder rungs. Lower rungs involve manipulation and therapy where education and therapy are used to gain public support. Middle rungs involve information, consultation, and placation. Only the higher rungs (partnership, delegation, and citizen control) actually give decisionmaking power to the citizen participants. Urban and community forestry programs tend to operate on the middle and upper rungs of this ladder.

The South Carolina Forestry Commission has an urban and community forestry (U\&CF) program that is funded through the USDA Forest Service (South Carolina Forestry Commission 2003b). South Carolina divides eligible proposals into three categories: community forestry program development or improvement, information and education, and nonprofit administration. Community forestry program development or improvement projects include the development of tree ordinances, tree inventory software, student internships, and greenspace inventories. Information and education projects include urban and community Arbor Day activities, workshops, and public service materials. Nonprofit administration projects include volunteer training, workshops, and temporary staffing. Six categories are used to define eligible recipients of these grants: municipal, county, state agency, university or college, nonprofit organization, and intermediate school. All of the grants offered by the South Carolina Forestry Commission involve one-to-one matching dollars.

In 2003, the South Carolina Forestry Commission awarded 32 grants that totaled US $\$ 230,000$ (South Carolina Forestry Commission 2003a). Examples of the projects that were funded include greenway development, urban and community forestry classes, tree planting and inventory staffing, and outdoor education.

The success of urban and community forestry programs depends upon the active participation of people in the community. In many cases, people do not know of the existence of the programs. Therefore, successful participation becomes a product of inspiring interest through education. A better understanding of what motivates people to take active interest in these programs will allow state, local, and nonprofit urban and community forestry organizations to evaluate future programs in terms of what has been successful, and what can be adjusted to be more effective.

Insight on public participation will enable state, local, and nonprofit organizations in South Carolina to identify what does and does not motivate individuals, communities, county and municipal decision-makers, various industries/ professionals, and others to participate in U\&CF programs or to embrace and adopt principles and approaches that improve urban and community forests.

The purpose of this study was to provide a perspective on what drives successful U\&CF programs, document the aspects of the programs that have achieved the greatest impact, and identify the various factors that encourage nonparticipants to become participants.

\section{STUDY METHODS}

In fall 2003, 324 South Carolina residents were surveyed to identify the characteristics of participants and nonparticipants in urban and community forestry programs and their attitudes toward the programs. Past participants were identified from South Carolina Forestry Commission records and represent $52 \%$ of those surveyed. The remaining 156 residents who had not participated in urban and community forestry programs were randomly selected statewide from occupational groups that would be expected to exhibit an equal interest in urban and community forestry (city/town officials, school educators, arborists, horticulturalists, foresters, consultants, foresters, and general public). Thus, nonparticipants in this survey represent people who might be expected to have an interest in or reason to participate in urban and community forestry programs. This helped to create a sample that was more sympatric than a completely randomized design. That is, the two groups (participants and nonparticipants) were similar in most characteristics. The nonparticipants were selected using tools such as phone books, occupational directories, and references from county foresters. Also, both groups were equally diverse in term of geographical location across the state and community size.

The survey was distributed through the mail and incorporated the Dillman Total Design Method (Dillman 1978). We received a total of 192 responses, representing a $59 \%$ response rate. Of this, approximately $56 \%$ of the 
respondents had participated in urban and community forestry programs, while the other $44 \%$ had not.

The survey instrument was kept short to increase the response rate. It contained 21 questions on three pages. Eighteen of the questions were multiple choice. Questions on level of participation and expected future participation were scaled. In addition to demographic data, participants were asked to describe the types of activities they have participated in, why they participated, when they participated, and what their attitudes toward these programs were. Nonparticipants were asked why they have not participated, whether they think they will participate in the future, and what could be done in the future to make these programs more appealing. The three open-ended questions gave respondents the opportunity to provide specific information that might have been overlooked had we provided a set of answer choices.

\section{RESULTS AND DISCUSSION}

Participant and nonparticipant characteristics can be seen in Tables 1 through 6 . Some of the tables represent descriptive data that did not lend itself to statistical analysis. Statistical analysis is included where appropriate, and key differences are analyzed. All chi-square test statistics relate to significant differences between participants and nonparticipants, unless otherwise stated. The majority of the respondents were male (66\%). Participants tended to be younger than nonparticipants. Forty-eight percent of the participants were between the ages of 30 and 49 years old, while $43 \%$ of the nonparticipants were between 50 and 65 years of age. The majority of both groups were married ( $80 \%$ and $78 \%$, respectively). Many ( $42 \%$ ) of the participants were from South Carolina's lower coastal plain region, likely due to the dramatic role played by tourism in the Charleston area.

At the 0.05 level of significance, only age showed a significant difference between participants and nonparticipants, suggesting the two populations are very similar in the other categories surveyed. Close observation of age groups (Table 1) suggests that participants were much more likely than nonparticipants to be 30 to 49 years old. Therefore we tested the 30- to 49-year age group against all other ages and found participants to be significantly more likely to be 30 to 49 years old (sample size $=191$, chi-square $=8.22, P=$ $0.04, \mathrm{DF}=3$ ). Table 1 data also suggest that participants are much more likely to come from upstate and the lower coastal plain than the upper coastal plain. However, we did not find a significant relationship concerning geography (sample size $=189$, chi-square $=2.22, P=0.33, \mathrm{DF}=2)$.

Educational level was high (Table 2). The majority of both groups graduated from college, and over one-third of each group earned a graduate-level degree. Only 22\% of the participants worked as arborists, horticulturist, or foresters (Table 3). Given that this occupation group is likely to be heavily involved in U\&CF projects, this is an encouraging
Table 1. Comparison of gender, age, marital status, and region of residence of participants versus nonparticipants.

\begin{tabular}{lcc}
\hline Characteristic & \% of participants & \% of nonparticipants \\
\hline Gender & & \\
Male & & 70 \\
Female & 63 & 30 \\
Age & 37 & \\
$<30$ years old & 3 & 10 \\
$30-49$ years old & 48 & 31 \\
$50-65$ years old & 38 & 43 \\
$>65$ years old & 11 & 16 \\
Marital status & & \\
Never married & 9 & 8 \\
Married & 80 & 78 \\
Separated & 0 & 2 \\
Widowed & 0 & 4 \\
Divorced & 11 & 8 \\
Region of residence & & \\
Upstate & 32 & 28 \\
Upper coastal plain & 26 & 36 \\
Lower coastal plain & 42 & 36 \\
\hline
\end{tabular}

${ }^{2}$ Sample size $=192$, chi-square $=1.12(P=0.29, \mathrm{DF}=1)$.

${ }^{\mathrm{y}}$ Sample size $=191$, chi-square $=8.22(P=0.04, \mathrm{DF}=3)$.

xample size $=190$, chi-square $=6.88(P=0.14, \mathrm{DF}=4)$.

${ }^{\text {wSample size }}=189$, chi-square $=2.22(P=0.33, \mathrm{DF}=2)$.

statistic. Certainly, information and education programs are least effective when "preaching to the choir." The audience of these programs appears to be people newly introduced to U\&CF concepts. Only 14\% of nonparticipants belonged to the arborist/horticulturist/forester occupational group. Both groups tended to be "middle-income" families (Table 4). Educational level, occupation group, and income level did not produce significant differences between the two groups. However, a related question is whether the arborist/horticulturist/forester is more likely to be a participant than other occupation groups. No significant difference was found to exist between that group and the other occupational groups.

One aspect of the survey questioned whether there would be a difference in participation based on the environment where a person was raised, as compared to the environment where they now lived (Table 5). Just over half of both participants and nonparticipants were raised in an urban or suburban area, and nearly two-thirds of both groups now lived in the urban or suburban area. Because likely participants of U\&CF programs were surveyed, this geography is not surprising. Table 6 shows that the majority of both groups were represented by people living in family households (roughly 80\%). Significant differences between the two groups did not exist due to early environment, current residence, or household environment.

Why people did or did not participate in these programs is of interest to program managers and administrators. 
Table 2. Comparison of level of education of participants versus nonparticipants.

\begin{tabular}{lcc}
\hline Education $^{*}$ & \% of participants & $\%$ of nonparticipants \\
\hline Elementary school & 0 & 1 \\
High school or equivalent & 4 & 6 \\
Associate (2-year) degree & 8 & 11 \\
Some college & 6 & 10 \\
College degree & 38 & 35 \\
Graduate degree & 44 & 37 \\
\hline
\end{tabular}

"Sample size $=190$, chi-square $=3.914(P=0.56, \mathrm{DF}=5)$.

Table 3. Comparison of level of job title of participants versus nonparticipants.

\begin{tabular}{lll}
\hline & \% of & \% of \\
Job title & participants & nonparticipants \\
\hline Arborist/horticulturist/forester & 22 & 14 \\
Director/coordinator & 18 & 14 \\
Consultant & 3 & 2 \\
Educator & 11 & 20 \\
Superintendent/manager & 11 & 14 \\
Planner & 19 & 12 \\
Other & 16 & 24
\end{tabular}

${ }^{2}$ Difference between participants and nonparticipants;

sample size $=190$, chi-square $=6.9314(P=0.33, \mathrm{DF}=6)$.

yParticipants more likely to be arborist/horticulturist/forester;

sample size $=190$, chi-square $=1.7134(P=0.19, \mathrm{DF}=1)$.

Table 4. Comparison of level of annual salary (U.S. dollars) of participants versus nonparticipants.

\begin{tabular}{lcc}
\hline Annual salary* $^{*}$ & \% of participants & $\%$ of nonparticipants \\
\hline$\$ 0-\$ 30,000$ & 9 & 7 \\
$\$ 30,00-\$ 85,000$ & 59 & 56 \\
$>\$ 85,000$ & 32 & 37 \\
\hline
\end{tabular}

${ }^{1}$ Sample size $=181$, chi-square $=0.5608(P=0.76, \mathrm{DF}=2)$.

Participants were asked about their primary and secondary reasons for participating (Table 7). Twenty-one percent described their primary reason for participation as a job requirement (i.e., they were paid to participate), and nearly half described their motivation as a professional or jobrelated interest. Forty-three percent stated their secondary reason as a personal interest. Nonparticipants were also questioned as to why they have not participated (Table 8). Seventy-one percent stated that they did not know of these programs. Only 33\% of nonparticipants stated that they would likely participate in the future. But over half stated they simply did not know about future participation. These results were expected due to the selection criteria.

Does knowledge of the U\&CF program affect respondents' expectations of future participation? We compared
Table 5. Comparison of participants versus nonparticipants based on early environment raised and current residence.

\begin{tabular}{llllll}
\hline & \multicolumn{2}{c}{$\%$ of participants } & & \multicolumn{2}{c}{ \% of nonparticipants } \\
\cline { 2 - 3 } \cline { 5 - 6 } Environment & $\begin{array}{l}\text { Area } \\
\text { raised }\end{array}$ & $\begin{array}{l}\text { Currently } \\
\text { reside }\end{array}$ & & $\begin{array}{l}\text { Area } \\
\text { raised }\end{array}$ & $\begin{array}{l}\text { Currently } \\
\text { reside }\end{array}$ \\
\hline Rural nonfarm & 22 & 23 & 21 & 24 \\
Rural farm & 26 & 15 & 27 & 11 \\
Suburban & 38 & 39 & 40 & 41 \\
Urban & 14 & 23 & 12 & 24 \\
\hline
\end{tabular}

${ }^{2}$ Area raised sample size $=187$, chi-square $=0.1146$

$(P=0.99, \mathrm{DF}=3)$

${ }^{y}$ Currently reside sample size $=190$, chi-square $=0.8165$

$(P=0.85, \mathrm{DF}=3)$

Table 6. Comparison of participants versus nonparticipants based on household environment.

\begin{tabular}{lll}
\hline $\begin{array}{l}\text { Household } \\
\text { environment }\end{array}$ & $\begin{array}{l}\text { \% of } \\
\text { participants }\end{array}$ & $\begin{array}{l}\text { \% of } \\
\text { nonparticipants }\end{array}$ \\
\hline Family household w/o children & 44 & 49 \\
Family household w/children $\leq 18$ & 38 & 30 \\
Female householder w/children $\leq 18$ & 1 & 4 \\
Male householder w/children $\leq 18$ & 1 & 2 \\
Householder living alone & 16 & 15 \\
\hline
\end{tabular}

"Sample size $=188$, chi-square $=3.1242(P=0.54, \mathrm{DF}=4)$.

future intentions of participation of nonparticipants who originally did not know about the program. Awareness of the program created a significant difference between those who would definitely or probably participate in U\&CF programs in the future and those who did not know or would definitely or probably not participate in the future (sample size $=84$, chi-square $=2.89, P=0.089, \mathrm{DF}=1$ ).

When asked for feelings about future participation, $64 \%$ of participants said they would definitely be involved in more programs (Table 9). Seventy-seven percent felt that these programs were very important. Time of participation in U\&CF programs was important (Table 10). Fifty-two percent have participated on a weekday, when they were paid to do so. Twenty-one percent have participated on weekdays that were unpaid.

Three of the questions were open-ended and designed to address issues related to what participants felt the best aspects of the programs were and what could be done in the future to make the programs more appealing (Tables 11 through 13). This provided an opportunity for ideas to surface that may not have been covered by the earlier questions. The most popular aspect of the program was the opportunity for grant funding (Table 11). However, other common responses were education, community involvement, and tree preservation. To get a better idea about the 
Table 7. Primary and secondary reasons for participation in urban and community forestry programs.

\begin{tabular}{llc}
\hline & \% of & \% of \\
Reasons & primary reason & secondary reason \\
\hline Professional/job requirement & 21 & 4 \\
Professional/job interest & 48 & 33 \\
Personal interest & 11 & 43 \\
Community requirement & 5 & 4 \\
Community interest & 11 & 11 \\
Other & 4 & 5 \\
\hline
\end{tabular}

Table 8. Reasons for nonparticipation and expectations for future participation.

\begin{tabular}{lclc}
\hline Reasons & $\begin{array}{l}\text { \% of non- } \\
\text { participants }\end{array}$ & Expectations & $\begin{array}{c}\text { \% of non- } \\
\text { participants }\end{array}$ \\
\hline Limited time & 20 & Definitely will & 4 \\
Not interested & 4 & Probably will & 29 \\
$\begin{array}{l}\text { Did not know } \\
\quad\end{array}$ & & \\
of programs & 71 & Don't know & 59 \\
Limited budget & 3 & Probably won't & 8 \\
Other & 2 & Definitely won't & 0 \\
\hline
\end{tabular}

Table 9. Expectations for future participation and attitudes toward urban and community forestry programs.

\begin{tabular}{llll}
\hline & \% of & & $\%$ of \\
Expectations & participants & Attitudes & participants \\
\hline Definitely will & 64 & Very important & 77 \\
Probably will & 27 & Somewhat important & 20 \\
Don't know & 6 & Don't know & 3 \\
Probably won't & 2 & Not important & 0 \\
Definitely won't & 1 & & \\
\hline
\end{tabular}

Table 10. Time during which people participated.

\begin{tabular}{ll}
\hline Time of participation & $\%$ of participants \\
\hline Weekday/paid & 52 \\
Weekday/unpaid & 21 \\
Weeknight/paid & 2 \\
Weeknight/unpaid & 8 \\
Weekend/paid & 1 \\
Weekend/unpaid & 16 \\
\hline
\end{tabular}

types of programs that people have participated in, we asked them to describe their activities. Activities such as tree plantings/inventories, Arbor Day events, and landscape beautification projects were the most common responses (Table 12).

Another very important consideration for the future of urban and community forestry programs is what needs to
Table 11. Participant's attitudes toward best aspect of urban and community forestry programs (number of responses).

Grant funding (58)

Education/demonstration (30)

Environmental improvements (28)

Community involvement (26)

Tree preservation (19)

Table 12. Types of activities participated in (number of responses).

Tree planting/inventories (47)

Workshops (40)

Arbor Day events (32)

Grant projects (23)

Landscape beautification projects (19)

Table 13. Future considerations to increase program appeal (number of responses).

Increase information to public/publicity/advertising (61)

More competitive grants/larger grants (53)

Increased flexibility in use of funds (21)

Networking (10)

Increase frequency of program opportunities (9)

Community involvement (7)

be done to make these programs better. All respondents were asked what could be done to increase program appeal (Table 13). The most common response was the need for more awareness. This directly relates to Table 8 , which shows that $71 \%$ of people who have never participated in U\&CF programs simply did not know of their existence. This is a major concern for the future of these programs. Other responses include the need for more networking, increased community involvement, and more flexibility in the use of grant money. The networking/community involvement comments seem to suggest a recommendation for increased interaction with other community leaders and organizations. Urban and community forestry programs could be a more integral part of the community, rather than a grant-supported interest group.

Responses to these questions reveal a few key facts. People recognize the value of these programs. The majority of participants (77\%) stated that these programs were very important (Table 9). The opportunity for grant funding, along with community involvement and education, ranked highest on the list of best aspects of U\&CF programs. The level of participation and interest in urban and community forestry programs shows that they are considered valuable to communities. There is a need for community involvement in regard to making these programs successful and a key to gaining increased involvement is awareness. Respondents 
made it clear that there is not enough information available to the public concerning these programs and that the lack of grants was a limiting factor. Table 9 shows that $64 \%$ of participants will definitely participate in the future, while Table 8 shows that $59 \%$ of nonparticipants do not know whether they will ever participate. Awareness is a major factor influencing participation and the main area that can produce immediate increases in U\&CF program activity.

One consideration for this project was the possibility that some people identified as nonparticipants may have actually participated in U\&CF programs in the past. Because we obtained a list from the South Carolina Forestry Commission that identified all known individuals across the state who have participated, we feel that there should be minimal chance of any mixing between the two populations.

\section{CONCLUSION}

The opportunity for U\&CF programs in South Carolina is increasing with urbanization. The trend of South Carolina's development of rural lands is showing no signs of slowing anytime soon (Vesterby and Krupa 2001). Therefore, it will be important for individuals, agencies, organizations, and corporations to become involved in these programs.

The purpose of this study was to provide a perspective on what drives successful U\&CF programs and what aspects of these programs have achieved the greatest impact on program participation rates and satisfaction.

The primary concern is that the majority of nonparticipants tended to have no knowledge of the U\&CF programs available to their communities. This is a likely result of poor publicity. More emphasis needs to be placed on the awareness of these programs in order to draw people who are not directly related to the forest industry or community government. It is important that once someone has participated in U\&CF programs they are more likely to participate again in the future. The majority of participants believed that these programs are very meaningful and would definitely participate again in the future. This facts show that future participation is influenced by making people aware of the programs.

There are some considerations for future study. Emphasis needs to be placed more on the program design. Factors affecting participation as identified by this study need to be included in potential U\&CF program designs to evaluate future effectiveness. Lack of awareness of available urban and community forestry programs is a problem. The effectiveness of marketing strategies associated with these programs needs to be evaluated. More efficient methods of raising awareness seem to be essential for the continued success of urban and community forestry programs. The information presented in this paper should serve as a guideline for future development of these programs.

\section{LITERATURE CITED}

Alig, R.J., F. Bedford, R.J. Moulton, and L. Lee. 1999. Longterm projection of urban and developed land area in the United States. In Keep America Growing-Balancing Working Lands and Development: Conference Proceedings (CD-ROM). American Farmland Trust, Washington, DC, Additional information at www.farmland.org (accessed 3/24/05).

Alig, R.J., A.J. Plantinga, S. Ahn, and J.D. Kline. 2003. Land use changes involving forestry in the United States 1952 to 1997, with Projections to 2050. USDA Forest Service General Technical Report PNW-GTR-587. 92 pp.

Arnstein, S.R. 1969. A ladder of citizen participation. J. Am. Plan. Assoc. 35(4):216-224.

Cubbage, F.W., J. O'Laughlin, and C.S. Bullock. 1993. Forest Resource Policy. Wiley, New York, NY. 592 pp.

Dillman, D.A. 1978. Mail and Telephone Surveys: The Total Design Method. Wiley-Interscience, New York, NY. 325 pp.

Florida Division of Forestry. 2004. Urban and Community Forestry Grant Program. Tallahassee, FL. www.fldof.com/forest_management/cfa_urban_grants.html (accessed 3/24/05).

Heimlich, R.E., and W.D. Anderson. 2001. Development at the Urban Fringe and Beyond: Impacts on Agriculture and Rural Land. Economic Reporting Service Agricultural Economic Report No. 803. Washington, DC. 88 pp.

London, J.B., and N.L Hill. 2000. Land Conversion in South Carolina: State Makes the Top 10 List. Jim Self Center on the Future, Clemson University, Clemson, SC. 4 pp.

McPherson, E.G. 1994. Benefits and costs of tree planting and care in Chicago, pp. 115-133. In McPherson, E.G., D.J. Nowak, and R.A. Rowntree [Eds.]. Chicago's Urban Forest Ecosystem: Results of the Chicago Urban Forest Climate Project. USDA Forest Service General Technical Report NE-186.

National Arbor Day Foundation. 2004. Tree City USA. Nebraska City, NE. www.arborday.org/programs/ treecityusa.cfm (accessed 3/24/05).

Nowak, D.J. 1994. Air pollution removal by Chicago's urban forest, pp. 63-81 In McPherson, E.G., D.J. Nowak, and R.A. Rowntree [Eds.]. Chicago's Urban Forest Ecosystem: Results of the Chicago Urban Forest Climate Project. USDA Forest Service General Technical Report NE-186.

South Carolina Forestry Commission 2003a. Personal communications with statewide program coordinator and foresters about past participants in $\mathrm{U} \& \mathrm{CF}$ programs.

—. 2003b. Awards 2003 Urban \& Community Forestry Grants. Columbia, SC. www.state.sc.us/forest/ 03ucfgrant.pdf (accessed 3/24/05). 
2004. Urban and Community Forestry Grant Assistance Program. Columbia, SC. www.state.sc.us/ forest/ucfgrantbr.pdf (accessed 3/24/05).

USDA Forest Service. 2004. Urban Forestry: A Manual for the State Forestry Agencies in the Southern Region. www.urbanforestrysouth.usda.gov/pubs/ufmanual (accessed 3/24/05).

U.S. Department of Commerce, Bureau of the Census. 2000. Population Projections, Medium Level. Washington, DC. www.census.gov/population/www/projections/ popproj.html (accessed 3/24/05).

Vesterby, M., and K.S. Krupa. 2001. Major Uses of Land in the United States, 1997. Economic Reporting Service Statistical Bulletin No. 973. Washington, DC, 60 pp.

Wisconsin DNR. 2004. Urban \& Community Forestry Program Information. Madison, WI. www.dnr.state.wi.us/ org/land/forestry/UF/program (accessed 3/24/05).

Acknowledgments. Technical Contribution Number 4964 of the Clemson University Experiment Station. Support for this research was provided by a USDA Forest Service Urban and Community Forestry Assistance Grant awarded through the South Carolina Forestry Commission.

\section{${ }^{1 *}$ Professor \\ ${ }^{2}$ Graduate Research Assistant \\ Department of Forestry and Natural Resources \\ Clemson University \\ Box 340317}

Clemson, SC 29634-0317, U.S.

*Corresponding author: Thomas Straka.
Résumé. Cet article traite des résultats d'une enquête menée en 2003 auprès des résidants à la grandeur de l'état de la Caroline du Sud concernant les caractéristiques qui affectent la participation dans les programmes communautaires et urbains en foresterie. Les résultats ont pour but d'améliorer l'efficacité en regard de la planification et de l'organisation du programme au sein des commissions forestière de l'état. Les participants dans les programmes de foresterie communautaire et urbaine ont des sentiments très forts concernant limportance de ces programmes, et la majorité des participants (91\%) visent une participation continue. La majorité des non-partcipants (71\%) n'étaient pas au courant de l'existence de ces programmes et la plupart (59\%) ne savaient pas s'ils allaient seulement participer dans de futures programmes. Les considérations futures pour le succès pour le succès des programmes de foresterie urbaine et communautaire en Caroline du Sud doivent s'orienter vers une conscience accrue du public. Les principaux facteurs qui affectaient les intentions de participer à ce programme étaient $(P \leq 0,10)$ la niveau de conscientisation l'âge des participants.

Zusammenfassung. Dieser Artikel stellt die Ergebnisse einer 2003 durchgeführten, staatsweiten Umfrage unter Anwohnern von Südkarolina betreffend der Eigenschaften bezüglich der Teilnahme an urbanen und kommunalen Frostprogrammen dar. Die Ergebnisse sind dazu geeignet, die Effektivität der Programmplanung und der Organisation innerhalb der staatlichen Forstkommissionen zu verbessern. Die Teilnehmer von urbanen und kommunalen Frostprogrammen sehen deutlich die Bedeutung dieser Programme und die Mehrheit (91\%) möchte weiterhin daran teilnehmen. Die Mehrheit der Nichtteilnehmer (71\%) war sich der Existenz der Programme gar nicht bewusst und die meisten (50\%) konnten nicht sagen, ob sie in Zukunft daran teilnehmen würden. Weiter Überlegungen für den Erfolg von urbanen und kommunalen

Frostprogrammen in Südkarolina müssen sich auf eine steigende Öffentlichkeitsarbeit fokussieren. Das Bewusstsein für das Programm und das Alter der Teilnehmer $(P \leq 0,10)$ beeinflusste deutlich die angeführten Absichten, an den Programmen teilzunehmen.

Resumen. Este artículo reporta los resultados de un levantamiento en el 2003 entre los residentes en el estado de South Carolina concerniente a las características que afectan la participación en los programas forestales urbanos. Los resultados indican la efectividad de incrementar el programa de planeación y organización dentro de las comisiones forestales estatales. Los participantes en los programas urbanos valoran la importancia de estos proyectos y la mayoría (91\%) desean una participación continua. La mayoría de los no-participantes (71\%) desconocía la existencia de estos programas y otros (59\%) no sabían si iban a participar en futuros proyectos. Las consideraciones futuras para el éxito de los programas forestales comunitarios en South Carolina necesitan enfocarse sobre el incremento en la conciencia del público. La prioridad sobre la conciencia del programa y la edad de los participantes afectaron significativamente $(P \leq 0.10)$ las intenciones de participar. 